\title{
ANALYSIS OF THE BRAZILIAN STOCK MARKET THROUGH GRAPH CENTRALITY MEASURES
}

\author{
Mariana Duque Finkel ${ }^{1 *}$ and Renata R. Del-Vecchio ${ }^{2}$ \\ Received February 9, 2021 / Accepted September 19, 2021
}

\begin{abstract}
This article aims to analyze the shares that make up the Brazilian IBRX100 index, verifying which sectors had the greatest influence on the Stock Exchange in 2018, 2019, and 2020. For this purpose, the theory of graph centrality measures was used to discover the most central shares. A balance analysis of the graphs was also performed, since balanced graphs are more stable, generating a more predictable stock portfolio. This study may help investors to compose a safer stock portfolio and identify which stocks are most correlated with each other. The most central shares can aid in perceiving stock market trends.
\end{abstract}

Keywords: graphs, centrality measures, balanced graph, shares.

\section{INTRODUCTION}

Graphs are used to model problems involving objects and relationships between them. Graph theory has many applications. One is the analysis of asset behavior in a graph representing a network of financial instruments. This type of study has already been used to assess the financial market in some countries, such as the United States, (Boginsky et al., 2003, 2005 and 2006; Battiston 2004); Italy (D'errico et al., 2009; Battiston, 2004) and Brazil (Abreu et al., 2019).

Edges and vertices can have different types of meanings. For example, edges can mean the statistical correlation between two nodes and the vertices represent financial assets (Boginsky et al., 2003, 2005 and 2006). Another type of modeling can be the representation of companies as vertices, and the weighted edges representing the shareholding, i.e. the ratio of capital that a company holds in relation to another (Battiston, 2004; D'errico et al., 2009; Abreu et al., 2019).

According to Harary et al. 2002, analyzing the correlations can assist in predicting the behavior of the shares and facilitate the structuring of an investment portfolio more suited to the investor's interests These correlations can indicate whether the shares have similar or opposite behaviors by analyzing whether the price variation occurs in the same direction or not. These variations

\footnotetext{
*Corresponding author

${ }^{1}$ Universidade Federal Fluminense - UFF, RJ, Brazil - E-mail: mariana duque@id.uff.br - http://orcid.org/ 0000-00015220-0715

${ }^{2}$ Universidade Federal Fluminense - UFF, RJ, Brazil - E-mail: rrdelvecchio@id.uff.br - http://orcid.org/ 0000-00031400-2309
} 
can be represented by graphs with weighted edges, with positive or negative weights indicating similarity or dissimilarity. Signed graphs are a peculiarity of those weighted graphs in which the weight of the edge can take on a value of $-1,+1$ or 0 . According to Cartwright's Principle and Harary's equilibrium theory 1956, unbalanced graphs are more unstable, so that the kind of relationship between the edges may change more frequently, meaning that the behavior of the graph is more unpredictable.

From the representation of the model in a graph, a centrality study can also be carried out to discover the most central vertices. There are different types of measures, including degree centrality, proximity, intermediation, eigenvector centrality, among others. In order to carry out this analysis, it is necessary to consider the characteristics of the "object" to be studied, what is the goal to be achieved to determine which is the best centrality measure to be employed.

Centrality theory has also been applied in the financial market. In Battiston, 2004, D'errico et al., 2009 and Abreu et al., 2019, weighted graphs are used to identify investment control. The centrality in-degree and out-degree measure respectively the number of controllers of an asset and the number of assets controlled by a single holder. In D'errico et al. 2009 intermediation and flow betweenness centralities were also used. Through centrality measures, it was also possible to identify the most central companies in the role of transferring information flows. Other types of centralities can be used to obtain other information.

Other approaches to the subject in question can be seen in Gartner (2012), where Markowitz's classic model is used along with an entropy-based model, and in Lopes (2013), who employs a multicriteria decision model. Another one, index tracking, is a strategy used to track a market index, that is, to pick a portfolio of stocks whose performance roughly reflects the behavior of the index. The choice of shares that make up this index is, in general, performed by optimization methods, such as mixed-integer programming (MIP). This method works well for solving small sized problems. However, in cases of high-dimensional problems, the method may not be feasible. Computational complexity is one of the reasons for the difficulty of these problems. More recently, the index tracking problem has been tackled using heuristic methods (Maringer et al., 2007).

In this article, measures of centrality in networks allow to compose a portfolio choosing the most central stocks, similarly to index tracking. However, centrality measures provide a complete ordering of the set of shares considered. This leads to observe stocks with a lower centrality value, helping to create portfolios with greater diversity. It is a relatively simple method, compared to those aforementioned, allowing an analysis of all shares.

Furthermore, in the methodology adopted in this work, we also analyzed stability characteristics through the concept of balanced signed graph, providing greater predictability of a portfolio when it corresponds to a balanced subgraph.

This paper will carry out an analysis of the stocks that make up the IBRX100 index, based on degree centrality, strength centrality and eigenvector centrality to assess which were the most important shares in the years 2018, 2019 and 2020. For last year, the period from January $1^{\text {st }}$, 
2020 to October $31^{\text {th }}, 2020$ was taken into consideration. The IBRX100 index is composed of the 100 most tradable and representative assets of the Brazilian stock market, according to information on the BM \& Bovespa website, the official stock exchange in Brazil. In this work, only the daily return of the shares that make up the index was considered, disregarding other parameters considered by this index.

In addition to the centrality analysis, it will be verified whether the graph that represents the correlations between the IBRX100 index shares is balanced. And it will also be verified if this index complies with a Power Law as in Boginsky et al. (2003, 2005 and 2006).

This article is structured in 5 sections. After this introduction, in Section 2, the graph theory used in the work will be introduced. Section 3 presents the methodology. The results are presented in Section 4 and the conclusion in Section 5.

\section{GRAPH THEORY}

Let $\mathrm{G}$ be a simple non-directed graph represented by $G=(V(G), E(G))$ in which its set of vertices is denoted by $V=V(G)$ and the set of edges by $E=E(G)$. A graph can be represented through an adjacency matrix $A(G)=\left(a_{i j}\right)$ of order $n \times n$, where $n$ is the number of vertices, being defined as:

$$
a_{i j}=\left\{\begin{array}{c}
1 \text { if }\{i, j\} \in E, \\
0 \text { otherwise, }
\end{array}\right.
$$

This representation can be extended to a weighted graph. In these graphs, weights are assigned to the edges, denoted by $w_{i j}$, which can be positive or negative values to indicate similarity or opposition, respectively. Therefore, in a weighted graph the inputs of the adjacency matrix are $w_{i j}$ if $\{\mathrm{i}, \mathrm{j}\} \in \mathrm{E}$ and 0 otherwise.

The spectrum of a graph is the set of its eigenvalues with its multiplicities. The eigenvalues of a graph, denoted by $\lambda$, are calculated using the equation $\operatorname{det}(\lambda I-A)=0$, where "I" is the identity matrix and " $\mathrm{A}$ " is the adjacency matrix of the graph.

\subsection{Balance analysis of a graph}

A signed graph $\mathrm{G}^{\sigma}=(\mathrm{G}, \sigma)$ consists of a graph $G=(V, E)$ and a mapping $\sigma: \mathrm{E} \rightarrow\{+,-\}$, called a sign function (or signature), on the edges of G. A signed graph can be seen as a weighted graph where each edge is labeled with the integers positive $(+1)$, negative $(-1)$ or null $(0)$ values. These graphs were introduced in 1953 by Harary (1953) to model social relations involving sympathy, indifference, and antipathy.

Cartwright's and Harary's equilibrium theory $(1953,1956)$ uses the graph cycle for balance analysis of a signed graph. Figure 1 shows two signed graphs in which the negative edges are represented by dashed lines and the positive edges by continuous lines. A graph is unbalanced if there is at least one negative cycle. Thereafter, graphs in which all edges have positive weights 
are balanced graphs. In Figure $1(b)$, one can see an unbalanced graph due to the cycle $\left\{e_{3}, e_{4}\right.$, $\left.e_{5}\right\}$.

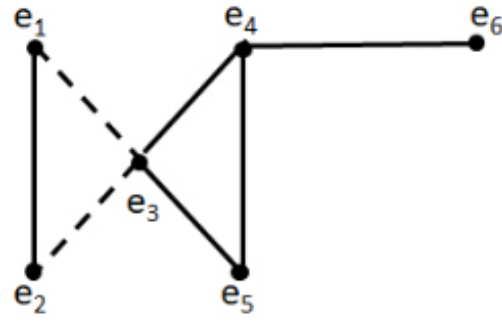

(a) balanced signed graph

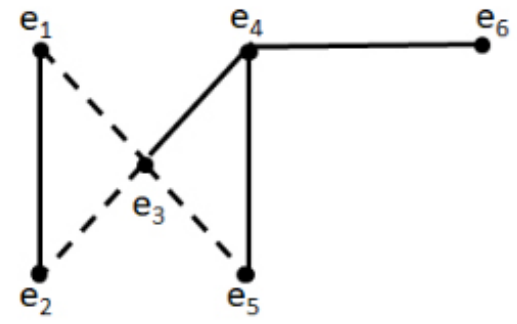

(b) unbalanced signed graph

Figure 1 - Example of balanced and unbalanced signed graph.

Eigenvalues also can be used to analyze the balance of a graph. In order to perform a balance analysis of a signed graph, we can use the signed Laplacian matrix, as defined below:

Definition 1. The Laplacian matrix $\bar{L}$ of a signed graph $\mathrm{G}$ with adjacency matrix $\mathrm{A}$ is given by $\bar{L}=\bar{D}-A$, where the signed degree matrix $\bar{D}$ is the diagonal matrix given by $\bar{D}_{i i}=\sum_{j \sim i}\left|a_{i j}\right|$.

Definition 2. A matrix is positive-definite if its eigenvalues are greater than zero.

Definition 3. A matrix is positive-semidefinite if its eigenvalues are greater or equal than zero.

The following two Theorems are well known, and can be found at Belardo (2014).

Theorem 1. The Laplacian matrix $\bar{L}$ is positive-semidefinite for any signed graph G.

Theorem 2. The Laplacian matrix of a signed graph is positive-definite if and only if the graph is unbalanced.

By Theorem 2, if the smallest eigenvalue of $\bar{L}(G)$ is zero, the signed graph will be balanced.

\subsection{Centrality}

Centrality measures enable us to identify the most central vertex. Thus, we were able to detect which is the most important vertex of the network. However, depending on the centrality measure used, we can achieve different results. To yield a good conclusion, we must choose the appropriate centrality measure according to the problem to be analyzed.

In this work, the centralities of degree, eigenvector and strength will be used.

\subsubsection{Degree Centrality}

Degree Centrality was introduced by Freeman (1978/79). It considers the nodes with highest degree the most central. The degree of the vertex is the number of edges that the vertex is directly 
connected to. This centrality can represent a measure of the direct influence of the interconnected vertices in a given node.

Definition 4. Let $\mathrm{G}$ be any graph (connected or not) with $n$ vertices and let $v_{k}$ be a vertex of G. The degree centrality of $v_{k}$, denoted by $d\left(v_{k}\right)$, is the number of edges incident to $v_{k}$. That is, $d\left(v_{k}\right)=\sum_{j=1}^{n} a_{k j}$ where $a_{k j}$ are elements of the adjacency matrix A (G).

Remark: The sum of the entries for each line in the adjacency matrix of a graph is equal to the degree of the corresponding vertex.

\subsubsection{Strength Centrality}

Strength centrality stems from an extension of degree centrality (Barrat et al., 2004; Newman, 2001). This centrality is used in weighted graphs. If the weight of all the edges of a vertex is equal to one, the degree and strength centralities will have the same value.

In this study, strength centrality represents the intensity of the direct correlations of the shares of the analyzed index.

Definition 5. Let $\mathrm{G}$ be any graph (connected or not) with $n$ vertices and let $v_{k}$ be a vertex of G. The strength centrality of $v_{k}$, denoted by $S C\left(v_{k}\right)$ is sum of weights of the edges that are incident to $v_{k}$. That is, SC $\left(v_{k}\right)=\sum_{j=1}^{n} w_{k j}$ where $w_{k j}$ represents each element of the line $\mathrm{k}$ of the matrix with the weights of the edges of the graph $\mathrm{G}$.

\subsubsection{Eigenvector Centrality}

This measure was introduced by Bonacich (1987). In addition, to considering the relevance of neighboring vertices, it also considers the importance of "neighbors of neighbors".

In this work, Eigenvector centrality will be used to analyze the spread of the correlation between the shares of the index.

Considering a graph $\mathrm{G}$, with all positive edges, the largest entries of the eigenvector of the adjacency matrix $A(G)$, associated with the largest eigenvalue correspond to the vertices with the greatest eigenvector centrality.

Definition 6. Let $\mathrm{G}$ be a connected graph on $\mathrm{n}$ vertices and let $v_{k}$ be a vertex of $\mathrm{G}$. The eigenvector centrality of $v_{k}$ is given by:

$$
c_{e i g}\left(v_{k}\right)=x_{k}
$$

where $x_{k}$ is the $\mathrm{k}$-th coordinate of the positive unit eigenvector $\mathrm{x}$ associated with the largest eigenvalue of $A(G)$, the adjacency matrix of the graph, denoted by $\rho$, that is,

$$
x_{k}=\frac{1}{\rho} \sum_{j=1}^{n} a_{k j} x_{j} ; k=1, \ldots, n
$$


Remark: The multiplicity of the largest eigenvalue of the adjacency matrix $\mathrm{A}(\mathrm{G})$ of a connected graph is equal to 1 , as a consequence of Perron-Frobenius Theorem (Horn and Johnson, 1985). Hence, any other positive eigenvector associated with the greater eigenvalue of $A(G)$ will be a scalar multiple of it. Therefore, let $x=\left(x_{1}, \ldots, x_{n}\right)$ and $y=\left(y_{1}, \ldots, y_{n}\right)$ be both positive eigenvectors associated with the largest eigenvalue of $\mathrm{A}(\mathrm{G})$. We have that $y=\alpha x$, where $\alpha>0$. Therefore, if $x_{i} \leq x_{j}$ then $y_{i} \leq y_{j}$, that is, any positive eigenvector associated with the largest eigenvalue of $\mathrm{A}(\mathrm{G})$ will induce the same order of the vertices.

\subsection{Power Law}

A network is called a scale-free network when the distribution of the degrees of its nodes obeys a Power Law. Many networks modeling real situations are scale-free. Boginsky et al. (2003) analyze a market graph and verify that the network follows the Power Law. Let $y$ be the number of nodes with degree $\mathrm{x}$, this law says that exists parameters $\alpha$ and $\beta$ such that:

$$
y=\frac{e^{\alpha}}{x^{\beta}}
$$

Equation 4 can be linearized and can be rewritten as follows:

$$
\log y=-\alpha \beta \log x
$$

Equation 5 can be represented graphically on a log-log scale corresponding to a negative slope line, where $-\beta$ is the slope and $\alpha$ is the intercept (Boginsky et al., 2003). The values of $\alpha$ and $\beta$ are obtained by linear regression of the following points $(\log x, \log y)$.

Graphs that obey a Power Law characteristically have a degree distribution in which most nodes have low degrees, and few nodes have high degrees (D'errico et al. 2009).

\section{METHODOLOGY}

In our study, we considered stock data for the set of 100 companies listed on the IBRX100 index on October 31st, 2020. The shares BIDI4, CNTO3, GNDI3, HAPV3, NEOE3, and PCAR3 were removed from the analysis because their price value is not included for all periods analyzed, years 2018, 2019, and 2020. This paper analyzed 94 of the 100 stocks that make up the index.

To perform the analysis, daily data on the closing prices of the shares belonging to the $\mathrm{IBrX} 100$ index were collected for the period of the year analyzed.

From these values, the daily return of the shares was calculated, thus normalizing the values to assess the data without impact of the differences in the amplitude of the share prices. With these data at hand, the relative correlation of each share was calculated in relation to the other shares that compose the analyzed index, thus forming a matrix of correlations of dimension $\mathrm{n} x$ $\mathrm{n}$, where $\mathrm{n}$ is the number of shares analyzed in the index. These data were used to calculate the strength centrality of the shares, which is based on the sum of the correlations, ordering the most 


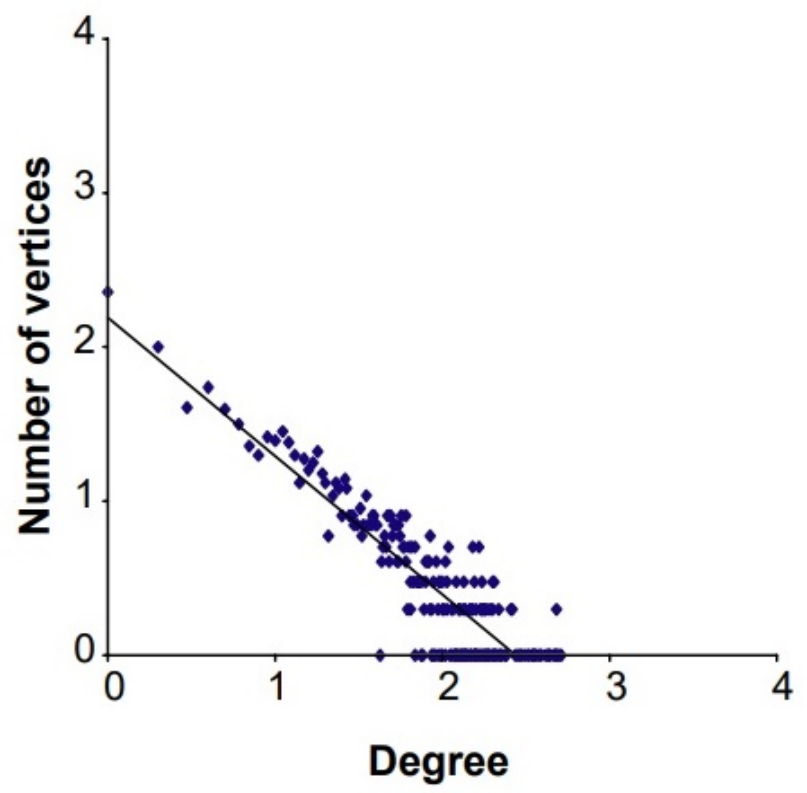

Figure 2 - Example of graph with degree distribution that follows a Power Law as described by Boginsky et al. (2005).

important shares with the highest value. To use the other techniques of the theory of centrality in graphs, it was necessary to transform the correlation matrix into an adjacency matrix. For this, a method similar to that applied by Boginsky et al. 2003, 2005 and 2006 was used, creating two parameters called "positive relevance factor" and "negative relevance factor", denoted by $\theta^{+}$e $\theta^{-}$, respectively. The value of $\theta^{+}$e $\theta^{-}$used in this work was the average of the positive and negative values of the correlations between the analyzed shares, respectively. Positive correlations with a value greater than $\theta^{+}$were assigned the value " 1 ", whereas positive correlations with a value less than this factor were assigned the value " 0 ". This same procedure was performed with negative correlations, with a value of " 1 " being attributed to correlations with values less than $\theta^{-}$, and " 0 " for shares with negative values greater than this factor.

From this procedure it was possible to generate an adjacency matrix of a signed graph, formed by the numbers $-1,0,1$. A Laplacian matrix was also generated, through the equation $\bar{L}=\bar{D}-A$.

The adjacency matrix represents a graph in which the nodes depict the shares and the edges correspond to the existence of a relevant positive or negative correlation between the assets (according to the relevance factors). To carry out the analysis of the balance of the graphs, the application of Theorem 2 (Page 3, line 23) was ensued. For the application of this Theorem, the eigenvalues of the signed Laplacian matrices of the IBrX100 index were calculated using MATLAB, and from the eigenvalues, it was observed whether the graphs were balanced. 
Boginsky et al. (2003) states that it is not to be expected to easily find a large group of negatively correlated instruments. Therefore, the IBRX100 index shares were expected to behave similarly and not to have negative correlations with each other. If there are few negative values and it does not harm the analysis, it is possible to remove the negative values (-1) from the adjacency matrix. In this case, zero was assigned to the entry of the adjacency matrix, which had a value of -1 . This procedure was used to allow an analysis regarding a centrality of degree and eigenvector, which is impaired by a matrix of negative values. The work carried out an analysis of the degree and eigenvector centralities of the IBrX100 index by means of adjacency matrices and the strength centrality by means of the correlation matrix of this index.

\section{RESULTS}

In this section, the results obtained will be described according to the methodology adopted in Section 3 .

\subsection{Balance analysis}

According to Theorem 2, by calculating the eigenvalues of the Laplacian matrix from the 2018 data, it was noticed that the signed graph was balanced, since the smallest eigenvalue had zero value. According to Harary et al. 2002, that graph has a more stable and predictable behavior.

Noting that the adjacency matrix related to the IBrX100 index had negative values concentrated in the stock of the company Suzano (SUZB3), we may suggest to an investor who wants to build up a balanced portfolio with hedge other IBrX100 shares whereas considering the SUZB3 stock as a hedge.

Although the calculation of the eigenvalues of the Laplacian matrix proves that the graph is balanced, due to the analysis of the centrality of the graphs being impaired by a signed graph, especially regarding the eigenvector centrality, SUZB3 stocks were removed. After removing it, the corresponding adjacency matrix was recalculated due to the change of the relevance factors ( $\theta^{+}$and $\theta^{-}$), as shown in Table 1 . Although the adjacency matrix after removing the shares has a negative value (-1) between the following shares: BRKM5 and ALSO3; EMBR3 and ALSO3; COGN3 and BPAN4; PSSA3 and BPAN4; JHSF3 and BRKM5; EMBR3 and ENEV3; ENEV3 and LCAM3; HGTX3 and KLBN11; HYPE3 and PRIO3; JHSF3 and KLBN11; NTCO3 and PRIO3, the graph remained balanced. In order to perform the centrality analysis, these values were considered equal to zero, transforming the signed graph into another graph, whose entries in the adjacency matrix are non-negative. Table 1 shows the values of $\theta^{+}$and $\theta^{-}$before and after removing the SUZB3 shares.

For the year 2019 it was observed that the graph was unbalanced due to its lower eigenvalue having a value other than zero, namely 0.2778 . The adjacency matrix had negative values $(-1)$ mainly between SUZB3 stock and some other IBrX100 stocks. A negative value was also found among the following shares: BRAP4 and ABEV3; VALE3 and ABEV3; CESP6 and BRDT3; CSNA3 and RADL3; PRIO3 and SULA11; TOTS3 and IRBR3. 
Table 1 - Relevance Factors in 2018.

\begin{tabular}{|c|c|c|}
\hline Case & Positive $\left(\theta^{+}\right)$ & Negative $\left(\theta^{-}\right)$ \\
\hline Before removing the SUZB3 share & 0.2926 & -0.0775 \\
After removing the SUZB3 share & 0.2938 & -0.0215 \\
\hline
\end{tabular}

To perform the centrality analysis, the SUZB3 shares were removed and the adjacency matrix was recalculated. It was observed that the graph remained unbalanced, whose lowest eigenvalue was 0.2885. The matrix had negative values among the following shares: BRAP4 and ABEV3; CESP6 and BRDT3; CCRO3 and LINX3; ABEV3 and VALE3; BPAN4 and TOTS3; RADL3 and CSNA3; EMBR3 and TOTS3; IRBR3 and PRIO3; HYPE3 and VALE3; IRBR3 and TOTS3; PETR4 and SULA11; PRIO3 and SULA11. These values were considered null allowing the transformation of a signed graph into a non-negative adjacency matrix, generating a balanced graph.

Table 2 - Relevance Factors in 2019.

\begin{tabular}{|c|c|c|}
\hline Case & Positive $\left(\theta^{+}\right.$ & Negative $\left(\theta^{-}\right)$ \\
\hline Before removing the SUZB3 share & 0.2619 & -0.0273 \\
After removing the SUZB3 share & 0.2652 & -0.0159 \\
\hline
\end{tabular}

In 2020, there was no negative correlation between the shares. According to the theory of equilibrium (Harary, 1953; Cartwright \& Harary, 1956), as the graph had no negative cycles, it was balanced. This year it was not necessary to remove the SUZB3 share.

Table 3 - Relevance Factors in 2020.

\begin{tabular}{|c|c|}
\hline Positive $\left(\theta^{+}\right.$ & Negative $\left(\theta^{-}\right)$ \\
\hline 0.5735 & - \\
\hline
\end{tabular}

It is observed in Tables 1, 2 and 3, that the values of $\theta^{+}$in the three years are greater than the values of $\theta^{-}$. In 2020, the value $\theta^{+}$was much higher than in other years. This year, the Coronavirus pandemic took place and some economic activities underwent government interference to prevent the spread of the virus.

\subsection{Power Law}

Boginsky et al. 2003, 2005 and 2006 and Battiston 2004 observed that the distribution of degrees of the assets analyzed obeyed a Power Law. Boginsky et al. $(2003,2005)$ noted that the Power Law structure is typical for many real-life datasets coming from diverse areas, concluding that the Power Law model is also applicable in finance. In view of these facts, we analyzed whether the IBRX100 index obeyed the Power Law with the relevance factor adopted ( $\theta)$. Thus, it is observed that the shares of the IBRX100 index of 2018, 2019 and 2020 do not obey a Power Law, according to Figure 3 below. 


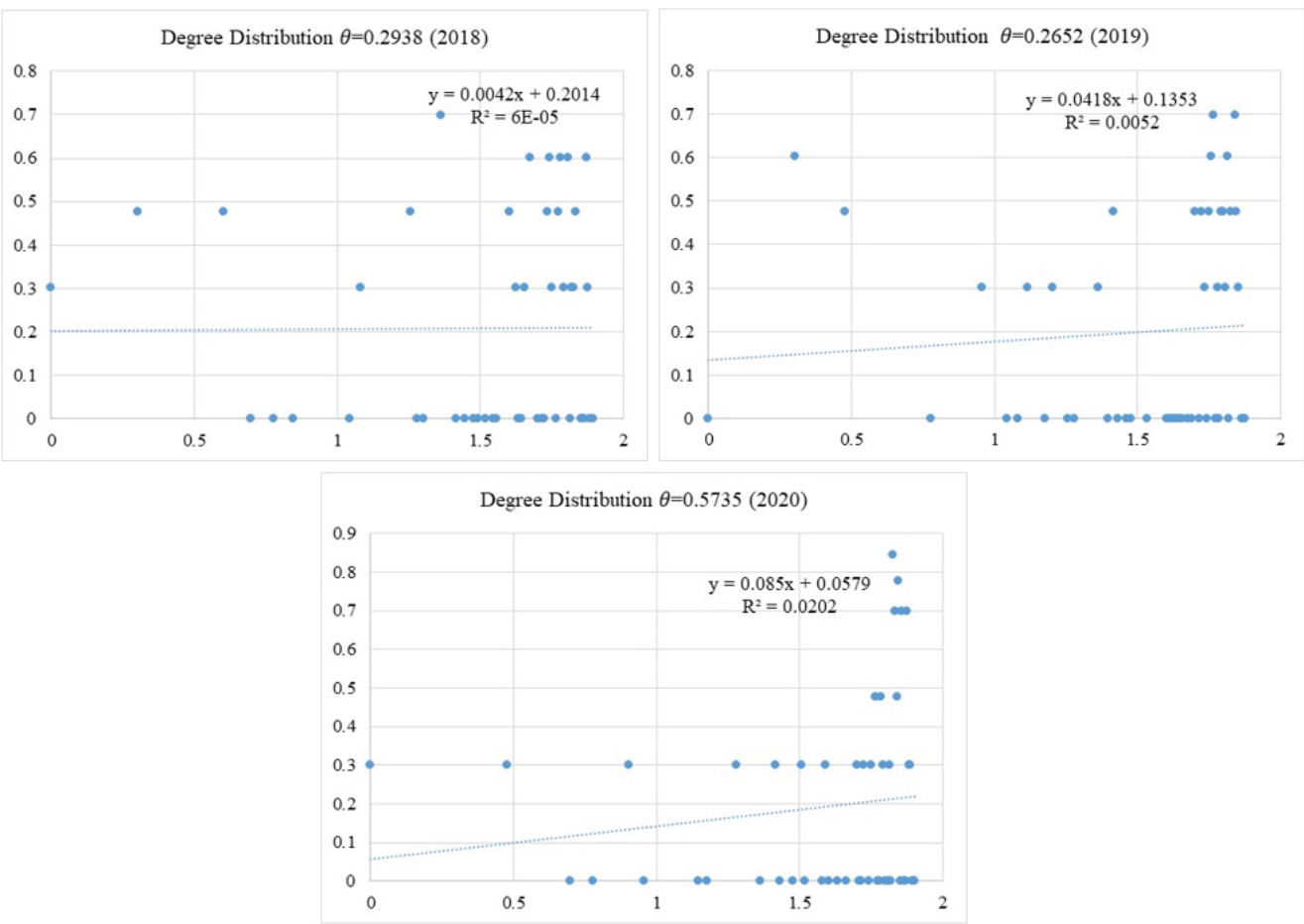

Figure 3 - Distribution of degree of shares for the years 2018, 2019 and 2020.

Boginsky et al. (2003) states that the relevance factor $(\theta)$ can influence the density of the edges (i.e., the ratio of the number of edges to the maximum possible number of edges) and the graph. For small values of relevance factor (in absolute value), there is a high edge density, making it difficult to analyze the graph. This paper concludes that, as the relevance factor increases, the degree distribution more and more resembles a Power law.

We verify this statement using the rounding up values of the adopted relevance factor and adding a variation of 0.05 . The result by Boginsky et al. (2003) was ratified, according to Figures 5 and 6. However, for the year 2018 this behavior was not observed (Figure 4).

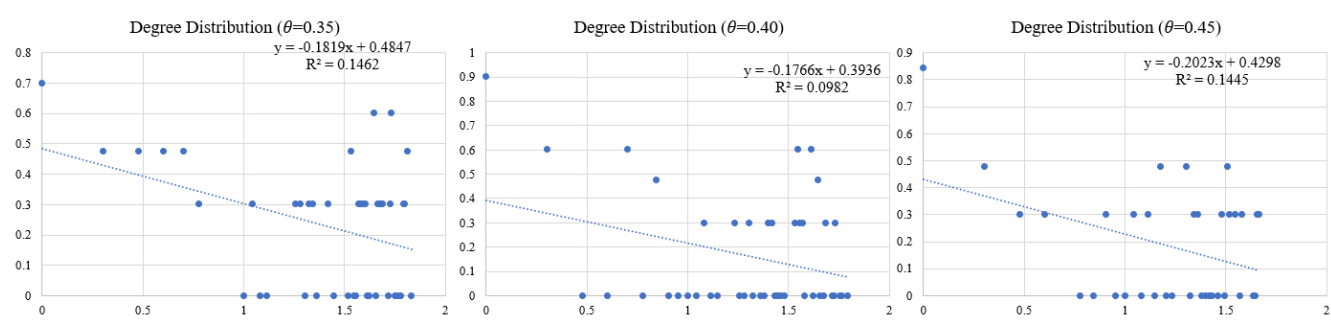

Figure 4 - Distribution of the degree of shares for different values of $\theta$ for the year 2018 . 

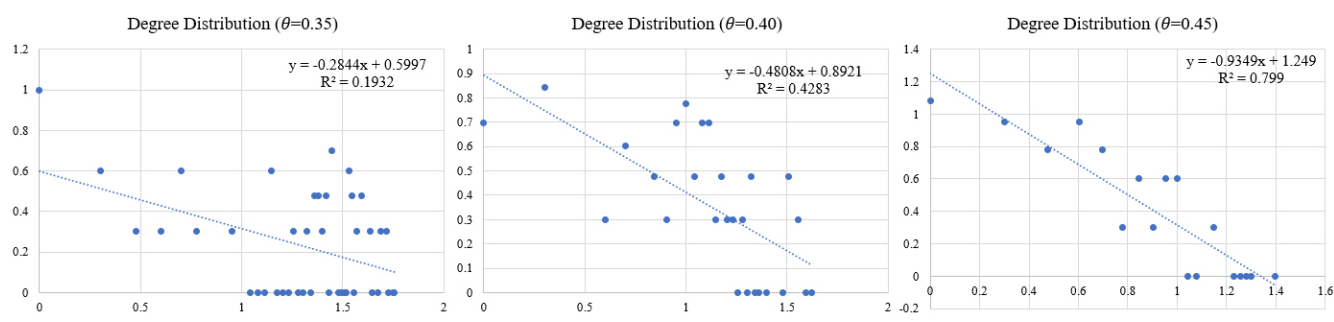

Figure 5 - Distribution of the degree of shares for different values of $\theta$ for the year 2019.

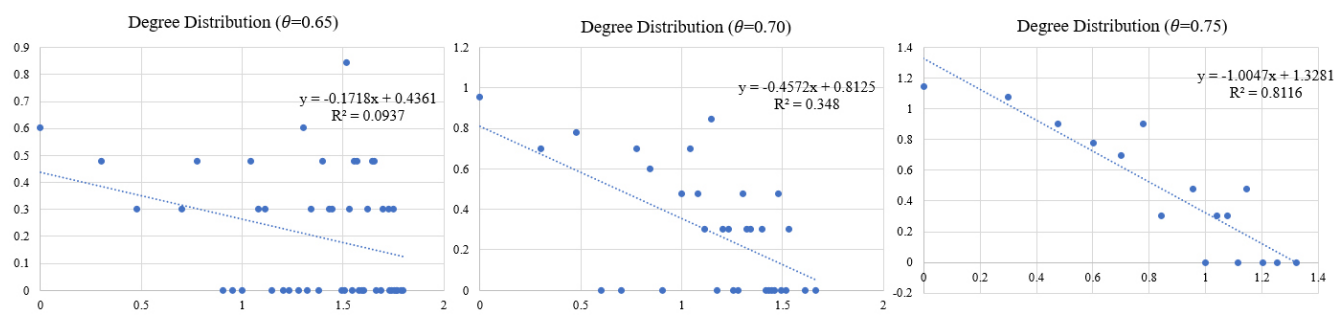

Figure 6 - Distribution of the degree of shares for different values of $\theta$ for the year 2020 .

\subsection{Centrality Analysis}

In this paper, the centrality of degree, eigenvector and strength were used. The strength centrality had a strict ordering in all years reaching $93^{\text {rd }}$ position in the years 2018 and 2019. In the year 2020 due to the inclusion of SUZB3 it reached $94^{\text {th }}$ position. Regarding the centralities of degree and eigenvector, some repeated positions occurred due to the centrality values being the same for some shares.

The lowest and highest values of the centralities and their positions are shown in Table 4. It can be seen from this table that the highest values of the strength centrality were in 2020, when a Coronavirus epidemic occurred.

The shares that had a null value of degree and eigenvector centralities were isolated in the graph because they had a lower correlation value than the adopted relevance factor. We can consider that these shares had a more distinctive behavior in relation to the others.

Table 4 - Position and values of the first and last positions of the centralities.

\begin{tabular}{|c|c|c|c|}
\hline Year & $\begin{array}{c}\text { Strength } \\
\text { Centrality }\end{array}$ & $\begin{array}{c}\text { Degree } \\
\text { Centrality }\end{array}$ & $\begin{array}{c}\text { Eigenvector } \\
\text { Centrality }\end{array}$ \\
\hline 2018 & $1^{\text {st }}-41.59$ & $1^{\text {st }}-78$ & $1^{\text {st }}-1$ \\
& $93^{\text {rd }}-7.51$ & $48^{\text {th }}-0$ & $86^{\text {th }}-0$ \\
\hline 2019 & $1^{\text {st }}-33.66$ & $1^{\text {st }}-75$ & $1^{\text {st }}-1$ \\
& $93^{\text {rd }}-10.79$ & $50^{\text {th }}-1$ & $86^{\text {th }}-0.001$ \\
\hline 2020 & $1^{\text {st }}-62.03$ & $1^{\text {st }}-80$ & $1^{\text {st }}-1$ \\
& $94^{\text {th }}-22.65$ & $50^{\text {th }}-0$ & $82^{\text {nd }}-0$ \\
\hline
\end{tabular}


Due to the strength centrality having a strict ordering, we can use this centrality for analysis the 10 most central shares in the years 2018, 2019 and 2020.

In 2018 the most central shares were predominantly from the banking sector. These are the main banks operating in the Brazilian market. It can also be seen that some of these shares were tied in the centralities of degree and eigenvector.

Shares of other sectors also had a high centrality value such as LAME3 and LAME4. These shares belong to Lojas Americanas, a retailer. LAME3 was the share in the best position in the centralities of degree and eigenvector, despite a worse position in the centrality strength in relation to the analyzed shares.

Through these centrality measures, we can conclude that bank shares have a greater intensity of interactions while Lojas Americanas' shares interact with a greater number of distinct shares belonging to the index.

Table 5 - Position and Centrality of the most central shares in 2018.

\begin{tabular}{|l|l|c|c|c|}
\hline Share & Economic Activity & $\begin{array}{c}\text { Strength } \\
\text { Centrality }\end{array}$ & $\begin{array}{c}\text { Degree } \\
\text { Centrality }\end{array}$ & $\begin{array}{c}\text { Eigenvector } \\
\text { Centrality }\end{array}$ \\
\hline ITUB4 & Banks & $1^{\text {st }} / 41.59$ & $3^{\text {rd }} / 75$ & $2^{\text {nd }} / 0.999$ \\
\hline ITSA4 & Banks & $2^{\text {nd }} / 41.25$ & $3^{\text {rd }} / 75$ & $2^{\text {nd }} / 0.999$ \\
\hline BBDC4 & Banks & $3^{\text {rd }} / 40.79$ & $4^{\text {th }} / 74$ & $3^{\text {rd }} / 0.994$ \\
\hline BBAS3 & Banks & $4^{\text {th }} / 40.25$ & $5^{\text {th }} / 73$ & $6^{\text {th }} / 0.983$ \\
\hline BBDC3 & Banks & $5^{\text {th }} / 39.96$ & $4^{\text {th }} / 74$ & $4^{\text {th }} / 0.992$ \\
\hline SANB11 & Banks & $6^{\text {th }} / 39.79$ & $4^{\text {th }} / 74$ & $3^{\text {rd }} / 0.994$ \\
\hline LAME4 & Miscellaneous Products & $7^{\text {th } / 38.77}$ & $2^{\text {nd } / 76}$ & $3^{\text {rd } / 0.994}$ \\
\hline MULT3 & Property Exploration & $8^{\text {th } / 38.05}$ & $4^{\text {th }} / 74$ & $5^{\text {th } / 0.986}$ \\
\hline B3SA3 & $\begin{array}{l}\text { Miscellaneous Financial } \\
\text { Services }\end{array}$ & $9^{\text {th } / 38}$ & $6^{\text {th } / 72}$ & $8^{\text {th } / 0.973}$ \\
\hline LAME3 & Miscellaneous Products & $10^{\text {th } / 37.19}$ & $1^{\text {st } / 78}$ & $1^{\text {st } / 1}$ \\
\hline
\end{tabular}

In 2019, we realized that the most central shares were more diversified. It can be considered that in this year, there was a greater predominance of the real estate sector as being the most central shares. The shares of MULT3, CYRE3, IGTA3 and BRML3 operate in the construction or real estate sector. 
We also observed that two companies in the retail sector are listed among the most central shares (LREN3 and LAME4). The LAME4 share was also among the most central shares of the year 2018 .

Table 6 - Position and Centrality of the most central shares in 2019.

\begin{tabular}{|c|c|c|c|c|}
\hline Share & Economic Activity & $\begin{array}{l}\text { Strength } \\
\text { Centrality }\end{array}$ & $\begin{array}{c}\text { Degree } \\
\text { Centrality }\end{array}$ & $\begin{array}{c}\text { Eigenvector } \\
\text { Centrality }\end{array}$ \\
\hline MULT3 & Property Exploration & $1^{\text {st }} / 33.66$ & $5^{\text {th }} / 70$ & $3^{\text {rd }} / 0.981$ \\
\hline CYRE3 & Incorporations & $2^{\text {nd }} / 33.25$ & $1^{\mathrm{st} / 75}$ & $1^{\mathrm{st}} / 1$ \\
\hline LREN3 & $\begin{array}{l}\text { Fabrics, Apparel and } \\
\text { Footwear }\end{array}$ & $3^{\mathrm{rd}} / 33.22$ & $2^{\text {nd }} / 74$ & $2^{\text {nd }} / 0.998$ \\
\hline CMIG4 & Electricity & $4^{\text {th }} / 33.06$ & $6^{\text {th }} / 69$ & $10^{\text {th }} / 0.960$ \\
\hline BBAS3 & Banks & $5^{\text {th }} / 32.81$ & $4^{\mathrm{th}} / 71$ & $11^{\mathrm{st}} / 0.958$ \\
\hline IGTA3 & Property Exploration & $6^{\text {th }} / 32.47$ & $4^{\text {th }} / 71$ & $5^{\text {th }} / 0.978$ \\
\hline B3SA3 & $\begin{array}{l}\text { Miscellaneous Financial } \\
\text { Services }\end{array}$ & $7^{\text {th }} / 32.3$ & $3^{\mathrm{rd}} / 73$ & $3^{\mathrm{rd}} / 0.981$ \\
\hline BRML3 & Property Exploration & $8^{\text {th }} / 31.47$ & $6^{\text {th }} / 69$ & $8^{\text {th }} / 0.965$ \\
\hline RENT3 & Car Rental & $9^{\text {th }} / 31.21$ & $5^{\text {th }} / 70$ & $6^{\text {th }} / 0.968$ \\
\hline LAME4 & Miscellaneous Products & $10^{\text {th }} / 31.07$ & $5^{\text {th }} / 70$ & $4^{\text {th }} / 0.979$ \\
\hline
\end{tabular}

It can be seen from Table 7 that, in 2020, there are also shares of different economic sectors among the most central. There was a predominance of the banking sector (BBAS3, BBDC3 and BBDC4). The second largest representation was of shares belonging to the economic activity of eletricity (CPLE6 and CMIG4) and exploration, refining and distribution (UGPA3 and CSAN3). The share that presented the greatest interconnection with the others was UGPA3, which presented greater degree and eigenvector centralities.

\section{CONCLUSIONS}

We can conclude that the most central shares varied according to the year. It is noticed that shares of the same economic sector can react in a similar way to factors external to the economy. The banking sector's shares were the most central both in 2018 and 2020. In 2019, these shares were in a worse position except for the BBAS3 share. 
Table 7 - Position and Centrality of the most central shares in 2020.

\begin{tabular}{|l|l|c|c|c|}
\hline Share & Economic Activity & $\begin{array}{c}\text { Strength } \\
\text { Centrality }\end{array}$ & $\begin{array}{c}\text { Degree } \\
\text { Centrality }\end{array}$ & $\begin{array}{c}\text { Eigenvector } \\
\text { Centrality }\end{array}$ \\
\hline CYRE3 & Incorporations & $1^{\text {st }} / 62.03$ & $5^{\text {st }} / 76$ & $4^{\text {st }} / 0.983$ \\
UGPA3 & Eanks & $2^{\text {nd }} / 61.69$ & $4^{\text {th }} / 77$ & $3^{\text {st }} / 0.990$ \\
ECOR3 & Highway Exploration & $3^{\text {rd }} / 61.08$ & $1^{\text {th }} / 80$ & $1^{\text {th }} / 1$ \\
BBDC3 & Banks & $5^{\text {th }} / 60.80$ & $5^{\text {th }} / 76$ & $6^{\text {th }} / 0.979$ \\
CPLE6 & Electricity & $6^{\text {th }} / 60.69$ & $4^{\text {th }} / 77$ & $5^{\text {th }} / 0.981$ \\
BBDC4 & Banks & $7^{\text {th }} / 60.06$ & $6^{\text {th }} / 75$ & $9^{\text {th }} / 0.972$ \\
CMIG4 & Electricity & $8^{\text {th }} / 60.04$ & $6^{\text {th }} / 75$ & $11^{\text {th }} / 0.965$ \\
CSAN3 & $\begin{array}{l}\text { Exploration, Refining and } \\
\text { Distribution }\end{array}$ & $9^{\text {th }} / 59.97$ & $3^{\text {th }} / 78$ & $7^{\text {th }} / 0.977$ \\
MOVI3 & Car Rental & $10^{\text {th }} / 59.89$ & $6^{\text {rd }} / 75$ & $8^{\text {nd }} / 0.975$ \\
\hline
\end{tabular}

In 2020, during the Coronavirus pandemic, the correlation between shares did not show negative values and featured higher values compared to previous years. It was noticed that shares from different sectors of the economy have had similar behavior, showing that the Coronavirus affected different sectors of the economy in a similar way.

As stated in Boginsky et al. (2003), the centrality of degree can help to evaluate the shares that have a greater correlation with the others. This information can help to assess which shares most reflect market behavior.

We also observed that the value of the relevance factor can affect the topology of the graph and its degree distribution, influencing the adherence to a Power Law.

Regarding balance, we can see that 2019 was the only year that the graph was unbalanced. The investor must first analyze the profitability of the shares and seek to build a balanced portfolio, as this will probably be more predictable and will have less risk of changes in positions.

The stocks that were isolated in the graph can also be an investment option seeking to diversify the portfolio with stocks that behave more independently of others. 
Concerning future work, it is possible to analyze the profitability of the shares and compare if it coincides with the most central shares.

\section{References}

[1] Abreu MP, Grassi R \& Del-Vecchio RR. 2019. Structure of Control in Financial Networks: an Application to the Brazilian Stock Market. Physica A, 522: 302-314.

[2] Barrat A, Barthelemy M, Pastor-Satorras R \& Vespignani A. 2004. The architecture of complex weighted networks. Proceedings of the National Academy of Sciences of the United States of America, 101(11): 3747-3752.

[3] Battiston S. 2004. Inner Structure of Capital Control Networks. Physica A, 338: 107112.

[4] BeLARDo F. 2014. Balancedness and the least eigenvalue of Laplacian of signed graphs. Linear Algebra and Its Applications, 446: 133-147.

[5] Boginsky V, Butenko S \& Pardalos P. 2003. On structural properties of the market graph. In: Innovations in Financial and Economic Networks.

[6] Boginsky V, Butenko S \& Pardalos P. 2005. Statistical Analysis of Financial Networks. Computational Statistics and Data Analysis, 48: 431-443.

[7] Boginski V, Butenko S \& Pardalos PM. 2006. Mining market data: A network approach. Computers \& Operations Research, 33(11): 3171-3184.

[8] B3: A BolsA Do BRASIL. 2020a. Available at: http://www.b3.com.br/pt $\backslash$ br/ market-data-e-indices/indices/indices-amplos/indice-brasil-100-ibrx-100.htm. Accessed in: 31 october 2020.

[9] B3: A BolsA DO BRASIL. 2020b. Available at: http://www.b3.com.br/pt \_br/ produtos-e-servicos/negociacao/renda-variavel/acoes/consultas/classificacao-setorial/. Accessed in 28 november 2020.

[10] BonACiCH P. 1987. Power and Centrality: a Family of Measures. The Americal Journal of Sociology, 92: 1170-1182.

[11] CARTwright D \& HARARY F. 1956. Structural balance: a generalization of Heider's theory. The Psychological Review, 63: 277-293.

[12] D’Errico M, Grassi R, Stefani S \& Torriero A. 2009. Shareholding Networks and Centrality: An Application to the Italian Financial Market. In: NAIMZADA AK, STEFANi S \& TORRIERO A. (eds), Networks, Topology and Dynamics. Lecture Notes in Economics and Mathematical Systems, 613. Berlin, Heidelberg: Springer. 
[13] Freeman LC. 1978/79. Centrality in Social Networks: Conceptual Clarification. Social Networks, 1: 215-239.

[14] GARTNER IR. 2012. Differentiated risk models in portfolio optimization: a comparative analysis of the degree of diversification and performance in the São Paulo Stock Exchange (BOVESPA). Pesquisa Operacional, 32(2): 271-292.

[15] HARARY F, LIM MH \& WUNSCH DC. 2002. Signed graphs for portfolio analysis in risk management. IMA Journal of Management Mathematics, 13: 201-210.

[16] HARARY F. 1953. On the notion of balance of a signed graph. The Michigan Mathematical Journal 2, 2: 143-146.

[17] Horn RA \& Johnson CR. 1985. Matrix Analysis, Cambridge University Press.

[18] Investing.com Brasil - FinançAs, CÂmbio E Bolsa de Valores. 2020. Available at: https://br.investing.com/indices/brazil-index-components. Accessed in: 31 october 2020.

[19] Lopes YG \& Almeida AT DE. 2013. A multicriteria decision model for selecting a portfolio of oil and gas exploration projects. Pesquisa Operacional, 33(3): 417-441

[20] MARINGer D \& OYewumi O. 2007. Index tracking with constrained portfolios. Intelligent Systems in Accounting, Finance and Management, 15(1-2):, 57-71.

[21] Newman MEJ. 2001. Scientific collaboration networks. II. Shortest paths, weighted networks, and centrality. Physical Review E 64: 016132.

\section{How to cite}

FinKel MD \& DEL-VECCHIO RR. 2021. Analysis of the brazilian stock market through graph centrality measures. Pesquisa Operacional, 41: e248549. doi: 10.1590/0101-7438.2021.041.00248549. 


\section{APPENDIX A}

Companies listed on the IBRX100 index. The table below describe the stocks listed on the IBRX100 on October 31th, 2020, and classify them by economic activity. This classification was obtained on the website of the Brazilian Stock Exchange (B3: A Bolsa do Brasil, 2020a).

\begin{tabular}{|c|c|c|}
\hline SHARE & COMPANY NAME & ECONOMIC ACTIVITY \\
\hline ABEV3 & Ambev SA & $\begin{array}{l}\text { Non-Cyclical Consumption / Beverages / } \\
\text { Beers and Soft Drinks }\end{array}$ \\
\hline ALPA4 & Alpargatas SA & $\begin{array}{l}\text { Cyclic Consumption / Fabrics, Apparel } \\
\text { and Footwear / Apparel }\end{array}$ \\
\hline ALSO3 & $\begin{array}{l}\text { Aliansce Sonae Shopping } \\
\text { Centers SA }\end{array}$ & $\begin{array}{l}\text { Finance / Property Exploration / Property } \\
\text { Exploration }\end{array}$ \\
\hline AMAR3 & $\begin{array}{l}\text { Marisa Lojas SA (LOJAS } \\
\text { MARISA) }\end{array}$ & $\begin{array}{l}\text { Cyclic Consumption / Trade / Fabrics, } \\
\text { Apparel and Footwear }\end{array}$ \\
\hline AZUL4 & Azul SA & $\begin{array}{l}\text { Industrial Goods / Transport / Air } \\
\text { Transport }\end{array}$ \\
\hline B3SA3 & B3 SA Brasil Bolsa Balcão & $\begin{array}{l}\text { Financial / Miscellaneous Financial } \\
\text { Services / Miscellaneous Financial } \\
\text { Services }\end{array}$ \\
\hline BBAS3 & Banco do Brasil SA & $\begin{array}{l}\text { Financial / Financial Intermediaries / } \\
\text { Banks }\end{array}$ \\
\hline BBDC3 & Banco Bradesco SA & $\begin{array}{l}\text { Financial / Financial Intermediaries / } \\
\text { Banks }\end{array}$ \\
\hline BBDC4 & Banco Bradesco SA & $\begin{array}{l}\text { Financial / Financial Intermediaries / } \\
\text { Banks }\end{array}$ \\
\hline BBSE3 & $\begin{array}{l}\text { BB Seguridade } \\
\text { Participações SA }\end{array}$ & $\begin{array}{l}\text { Financial / Pension and Insurance / } \\
\text { Insurance }\end{array}$ \\
\hline BEEF3 & Minerva SA & $\begin{array}{l}\text { Non-Cyclical Consumption / Processed } \\
\text { Foods / Meat and Meat Products }\end{array}$ \\
\hline
\end{tabular}




\begin{tabular}{|c|c|c|}
\hline SHARE & COMPANY NAME & ECONOMIC ACTIVITY \\
\hline BIDI4 & Banco Inter SA & $\begin{array}{l}\text { Financial / Financial Intermediaries / } \\
\text { Banks }\end{array}$ \\
\hline BPAC 11 & Banco BTG Pactual SA & $\begin{array}{l}\text { Financial / Financial Intermediaries / } \\
\text { Banks }\end{array}$ \\
\hline BPAN4 & Banco Pan SA & $\begin{array}{l}\text { Financial / Financial Intermediaries / } \\
\text { Banks }\end{array}$ \\
\hline BRAP4 & Bradespar SA & $\begin{array}{l}\text { Basic Materials / Mining / Metallic } \\
\text { Minerals }\end{array}$ \\
\hline BRDT3 & Petrobras Distribuidora SA & $\begin{array}{l}\text { Petroleum, Gas and Biofuels / Petroleum, } \\
\text { Gas and Biofuels / Exploration, Refining } \\
\text { and Distribution }\end{array}$ \\
\hline BRFS3 & BRF SA & $\begin{array}{l}\text { Non-Cyclical Consumption / Processed } \\
\text { Foods / Meat and Meat Products }\end{array}$ \\
\hline BRKM5 & Braskem SA & $\begin{array}{l}\text { Basic Materials / Chemicals / } \\
\text { Petrochemicals }\end{array}$ \\
\hline BRML3 & BR Malls Participações SA & $\begin{array}{l}\text { Finance / Property Exploration / Property } \\
\text { Exploration }\end{array}$ \\
\hline BTOW3 & B2W Cia Digital & $\begin{array}{l}\text { Cyclical Consumption / Trade / } \\
\text { Miscellaneous Products }\end{array}$ \\
\hline CCRO3 & CCR SA & $\begin{array}{l}\text { Industrial Goods / Transportation / } \\
\text { Highway Exploration }\end{array}$ \\
\hline CESP6 & Cesp & Public Utility / Electricity / Electricity \\
\hline CIEL3 & Cielo SA & $\begin{array}{l}\text { Financial / Miscellaneous Financial } \\
\text { Services / Miscellaneous Financial } \\
\text { Services }\end{array}$ \\
\hline CMIG4 & CEMIG & Public Utility / Electricity / Electricity \\
\hline
\end{tabular}




\begin{tabular}{|c|c|c|}
\hline SHARE & COMPANY NAME & ECONOMIC ACTIVITY \\
\hline CNTO3 & Grupo SBF Centauro & $\begin{array}{l}\text { Cyclical Consumption / Trade / } \\
\text { Miscellaneous Products }\end{array}$ \\
\hline COGN3 & Cogna Educação & $\begin{array}{l}\text { Cyclical Consumption / Miscellaneous / } \\
\text { Educational Services }\end{array}$ \\
\hline CPFE3 & CPFL ENERGIA & Public Utility / Electricity / Electricity \\
\hline CPLE6 & Copel & Public Utility / Electricity / Electricity \\
\hline CRFB3 & $\begin{array}{l}\text { Carrefour BR (Atacadão } \\
\text { SA) }\end{array}$ & $\begin{array}{l}\text { Non-Cyclical Consumption / Commerce } \\
\text { and Distribution / Food }\end{array}$ \\
\hline CSAN3 & Cosan & $\begin{array}{l}\text { Petroleum, Gas and Biofuels / Petroleum, } \\
\text { Gas and Biofuels / Exploration, Refining } \\
\text { and Distribution }\end{array}$ \\
\hline CSMG3 & Copasa & $\begin{array}{l}\text { Public Utility / Water and Sanitation / } \\
\text { Water and Sanitation }\end{array}$ \\
\hline CSNA3 & $\begin{array}{l}\text { Companhia Siderúrgica } \\
\text { Nacional (CSN) }\end{array}$ & $\begin{array}{l}\text { Basic Materials / Steel and Metallurgy / } \\
\text { Steel }\end{array}$ \\
\hline CVCB3 & $\begin{array}{l}\text { CVC Brasil Operadora e } \\
\text { Agencia de Viagens SA }\end{array}$ & $\begin{array}{l}\text { Cyclical Consumption / Travel and } \\
\text { Leisure / Travel and Tourism }\end{array}$ \\
\hline CYRE3 & Cyrela Brazil Realty SA & $\begin{array}{l}\text { Cyclical Consumption / Civil } \\
\text { Construction / Incorporations }\end{array}$ \\
\hline DTEX3 & Duratex SA & Basic Materials / Wood and Paper / Wood \\
\hline ECOR3 & $\begin{array}{l}\text { Ecorodovias Infraestrutura e } \\
\text { Logística SA }\end{array}$ & $\begin{array}{l}\text { Industrial Goods / Transportation / } \\
\text { Highway Exploration }\end{array}$ \\
\hline EGIE3 & Engie Brasil Energia SA & Public Utility / Electricity / Electricity \\
\hline ELET3 & Eletrobras & Public Utility / Electricity / Electricity \\
\hline ELET6 & Eletrobras & Public Utility / Electricity / Electricity \\
\hline
\end{tabular}




\begin{tabular}{|c|c|c|}
\hline SHARE & COMPANY NAME & ECONOMIC ACTIVITY \\
\hline EMBR3 & Embraer SA & $\begin{array}{l}\text { Industrial Goods / Transport Material / } \\
\text { Aeronautical and Defense Material }\end{array}$ \\
\hline ENBR3 & EDP Energias do Brasil SA & Public Utility / Electricity / Electricity \\
\hline ENEV3 & Eneva SA & Public Utility / Electricity / Electricity \\
\hline ENGI11 & Energisa SA & Public Utility / Electricity / Electricity \\
\hline EQTL3 & Equatorial Energia SA & Public Utility / Electricity / Electricity \\
\hline EZTC3 & $\begin{array}{l}\text { Eztec Empreendimentos e } \\
\text { Participações SA }\end{array}$ & $\begin{array}{l}\text { Cyclical Consumption / Civil } \\
\text { Construction / Incorporations }\end{array}$ \\
\hline FLRY3 & Fleury SA & $\begin{array}{l}\text { Health / Hospital Medical Service } \\
\text { Analysis and Diagnosis / Hospital } \\
\text { Medical Service Analysis and Diagnosis }\end{array}$ \\
\hline GGBR4 & Gerdau SA & $\begin{array}{l}\text { Basic Materials / Steel and Metallurgy / } \\
\text { Steel }\end{array}$ \\
\hline GNDI3 & $\begin{array}{l}\text { Notre Dame Intermédica } \\
\text { Participações SA }\end{array}$ & $\begin{array}{l}\text { Health / Hospital Medical Service } \\
\text { Analysis and Diagnosis / Hospital } \\
\text { Medical Service Analysis and Diagnosis }\end{array}$ \\
\hline GOAU4 & Metalúrgica Gerdau SA & $\begin{array}{l}\text { Basic Materials / Steel and Metallurgy / } \\
\text { Steel }\end{array}$ \\
\hline GOLL4 & $\begin{array}{l}\text { Gol Linhas Aéreas } \\
\text { Inteligentes SA }\end{array}$ & $\begin{array}{l}\text { Industrial Goods / Transport / Air } \\
\text { Transport }\end{array}$ \\
\hline HAPV3 & $\begin{array}{l}\text { Hapvida Participações e } \\
\text { Investimentos SA }\end{array}$ & $\begin{array}{l}\text { Health / Hospital Medical Service } \\
\text { Analysis and Diagnosis / Hospital } \\
\text { Medical Service Analysis and Diagnosis }\end{array}$ \\
\hline HGTX3 & CIA Hering & $\begin{array}{l}\text { Cyclic Consumption / Fabrics, Apparel } \\
\text { and Footwear / Apparel }\end{array}$ \\
\hline HYPE3 & Hypera SA & $\begin{array}{l}\text { Health / Commerce and Distribution / } \\
\text { Medicines and Other Products }\end{array}$ \\
\hline
\end{tabular}




\begin{tabular}{|c|c|c|}
\hline SHARE & COMPANY NAME & ECONOMIC ACTIVITY \\
\hline IGTA3 & $\begin{array}{l}\text { Iguatemi Empresa de } \\
\text { Shopping Centers SA }\end{array}$ & $\begin{array}{l}\text { Finance / Property Exploration / Property } \\
\text { Exploration }\end{array}$ \\
\hline IRBR3 & IRB Brasil Resseguros SA & $\begin{array}{l}\text { Financial / Pension and Insurance / } \\
\text { Insurance }\end{array}$ \\
\hline ITSA4 & $\begin{array}{l}\text { Itausa - Investimentos Itaú } \\
\text { SA }\end{array}$ & $\begin{array}{l}\text { Financial / Financial Intermediaries / } \\
\text { Banks }\end{array}$ \\
\hline ITUB4 & $\begin{array}{l}\text { Itaú Unibanco Banco } \\
\text { Holding SA }\end{array}$ & $\begin{array}{l}\text { Financial / Financial Intermediaries / } \\
\text { Banks }\end{array}$ \\
\hline JBSS3 & JBS SA & $\begin{array}{l}\text { Non-Cyclical Consumption / Processed } \\
\text { Foods / Meat and Meat Products }\end{array}$ \\
\hline JHSF3 & JHSF Participações SA & $\begin{array}{l}\text { Cyclical Consumption / Civil } \\
\text { Construction / Incorporations }\end{array}$ \\
\hline KLBN11 & Klabin SA & $\begin{array}{l}\text { Basic Materials / Wood and Paper / Wood } \\
\text { Pulp and Paper }\end{array}$ \\
\hline LAME3 & Lojas Americanas SA & $\begin{array}{l}\text { Cyclical Consumption / Trade / } \\
\text { Miscellaneous Products }\end{array}$ \\
\hline LAME4 & Lojas Americanas SA & $\begin{array}{l}\text { Cyclical Consumption / Trade / } \\
\text { Miscellaneous Products }\end{array}$ \\
\hline LCAM3 & $\begin{array}{l}\text { Cia de Locação das } \\
\text { Américas (LOCAMERICA) }\end{array}$ & $\begin{array}{l}\text { Cycle Consumption / Miscellaneous / Car } \\
\text { Rental }\end{array}$ \\
\hline LIGT3 & Light SA & Public Utility / Electricity / Electricity \\
\hline LINX3 & LINX SA & $\begin{array}{l}\text { Information Technology / Programs and } \\
\text { Services / Programs and Services }\end{array}$ \\
\hline LREN3 & Lojas Renner SA & $\begin{array}{l}\text { Cyclic Consumption / Trade / Fabrics, } \\
\text { Apparel and Footwear }\end{array}$ \\
\hline MDIA3 & $\begin{array}{l}\text { M Dias Branco SA Industria } \\
\text { e Comercio de Alimentos }\end{array}$ & $\begin{array}{l}\text { Non-Cyclical Consumption / Processed } \\
\text { Foods / Meat and Meat Products }\end{array}$ \\
\hline
\end{tabular}




\begin{tabular}{|c|c|c|}
\hline SHARE & COMPANY NAME & ECONOMIC ACTIVITY \\
\hline MGLU3 & Magazine Luiza SA & $\begin{array}{l}\text { Cyclical Consumption / Commerce / } \\
\text { Household Appliances }\end{array}$ \\
\hline MOVI3 & Movida Participações SA & $\begin{array}{l}\text { Cycle Consumption / Miscellaneous / Car } \\
\text { Rental }\end{array}$ \\
\hline MRFG3 & Marfrig Global Foods SA & $\begin{array}{l}\text { Non-Cyclical Consumption / Processed } \\
\text { Foods / Meat and Meat Products }\end{array}$ \\
\hline MRVE3 & $\begin{array}{l}\text { MRV Engenharia e } \\
\text { Participações SA }\end{array}$ & $\begin{array}{l}\text { Cyclical Consumption / Civil } \\
\text { Construction / Incorporations }\end{array}$ \\
\hline MULT3 & $\begin{array}{l}\text { Multiplan } \\
\text { Empreendimentos } \\
\text { Imobiliários SA }\end{array}$ & $\begin{array}{l}\text { Finance / Property Exploration / Property } \\
\text { Exploration }\end{array}$ \\
\hline NEOE3 & Neoenergia SA & Public Utility / Electricity / Electricity \\
\hline NTCO3 & Natura \& Co SA & $\begin{array}{l}\text { Non-Cyclical Consumption / Personal Use } \\
\text { and Cleaning Products / Personal Use } \\
\text { Products }\end{array}$ \\
\hline PCAR3 & $\begin{array}{l}\text { Pão de Açúcar Companhia } \\
\text { Brasileira de Distribuição }\end{array}$ & $\begin{array}{l}\text { Non-Cyclical Consumption / Commerce } \\
\text { and Distribution / Food }\end{array}$ \\
\hline PETR3 & $\begin{array}{l}\text { Petrobras - Petróleo } \\
\text { Brasileiro Petrobras SA }\end{array}$ & $\begin{array}{l}\text { Petroleum, Gas and Biofuels / Petroleum, } \\
\text { Gas and Biofuels / Exploration, Refining } \\
\text { and Distribution }\end{array}$ \\
\hline PETR4 & $\begin{array}{l}\text { Petrobras - Petróleo } \\
\text { Brasileiro Petrobras SA }\end{array}$ & $\begin{array}{l}\text { Petroleum, Gas and Biofuels / Petroleum, } \\
\text { Gas and Biofuels / Exploration, Refining } \\
\text { and Distribution }\end{array}$ \\
\hline PRIO3 & Petrorio SA & $\begin{array}{l}\text { Petroleum, Gas and Biofuels / Petroleum, } \\
\text { Gas and Biofuels / Exploration, Refining } \\
\text { and Distribution }\end{array}$ \\
\hline PSSA3 & Porto Seguro SA & $\begin{array}{l}\text { Financial / Pension and Insurance / } \\
\text { Insurance }\end{array}$ \\
\hline
\end{tabular}




\begin{tabular}{|c|c|c|}
\hline SHARE & COMPANY NAME & ECONOMIC ACTIVITY \\
\hline QUAL3 & Qualicorp SA & $\begin{array}{l}\text { Health / Hospital Medical Service } \\
\text { Analysis and Diagnosis / Hospital } \\
\text { Medical Service Analysis and Diagnosis }\end{array}$ \\
\hline RADL3 & RAIADROGASIL SA & $\begin{array}{l}\text { Health / Commerce and Distribution / } \\
\text { Medicines and Other Products }\end{array}$ \\
\hline RAIL3 & Rumo S.A. & $\begin{array}{l}\text { Industrial Goods / Transport / Rail } \\
\text { Transport }\end{array}$ \\
\hline RAPT4 & $\begin{array}{l}\text { Randon SA Implementos e } \\
\text { Participações }\end{array}$ & $\begin{array}{l}\text { Industrial Goods / Transport Equipment / } \\
\text { Road Equipment }\end{array}$ \\
\hline RENT3 & Localiza Rent a Car SA & $\begin{array}{l}\text { Cycle Consumption / Miscellaneous / Car } \\
\text { Rental }\end{array}$ \\
\hline SANB11 & Banco Santander Brasil SA & $\begin{array}{l}\text { Financial / Financial Intermediaries / } \\
\text { Banks }\end{array}$ \\
\hline SAPR11 & $\begin{array}{l}\text { Companhia de Saneamento } \\
\text { do Paraná (SANEPAR) }\end{array}$ & $\begin{array}{l}\text { Public Utility / Water and Sanitation / } \\
\text { Water and Sanitation }\end{array}$ \\
\hline SBSP3 & $\begin{array}{l}\text { Cia Saneamento Básico do } \\
\text { Estado de São Paulo } \\
\text { (SABESP) }\end{array}$ & $\begin{array}{l}\text { Public Utility / Water and Sanitation / } \\
\text { Water and Sanitation }\end{array}$ \\
\hline SULA11 & Sul América SA & $\begin{array}{l}\text { Financial / Pension and Insurance / } \\
\text { Insurance }\end{array}$ \\
\hline SUZB3 & Suzano S.A. & $\begin{array}{l}\text { Basic Materials / Wood and Paper / Wood } \\
\text { Pulp and Paper }\end{array}$ \\
\hline TAEE11 & $\begin{array}{l}\text { Transmissora Aliança de } \\
\text { Electricity SA (TAESA) }\end{array}$ & Public Utility / Electricity / Electricity \\
\hline TIMS3 & Tim Participações SA & $\begin{array}{l}\text { Communications / Telecommunications / } \\
\text { Telecommunications }\end{array}$ \\
\hline TOTS3 & TOTVS SA & $\begin{array}{l}\text { Information Technology / Programs and } \\
\text { Services / Programs and Services }\end{array}$ \\
\hline
\end{tabular}




\begin{tabular}{|c|c|c|}
\hline SHARE & COMPANY NAME & ECONOMIC ACTIVITY \\
\hline TRPL4 & $\begin{array}{l}\text { Cia de Transmissão de } \\
\text { Electricity Paulista } \\
\text { (CTEEP) }\end{array}$ & Public Utility / Electricity / Electricity \\
\hline UGPA3 & $\begin{array}{l}\text { ULTRAPAR } \\
\text { PARTICIPACOES SA }\end{array}$ & $\begin{array}{l}\text { Petroleum, Gas and Biofuels / Petroleum, } \\
\text { Gas and Biofuels / Exploration, Refining } \\
\text { and Distribution }\end{array}$ \\
\hline USIM5 & $\begin{array}{l}\text { Usinas Siderúrgicas de } \\
\text { Minas Gerais SA } \\
\text { (USIMINAS) }\end{array}$ & $\begin{array}{l}\text { Basic Materials / Steel and Metallurgy / } \\
\text { Steel }\end{array}$ \\
\hline VALE3 & Vale SA & $\begin{array}{l}\text { Basic Materials / Mining / Metallic } \\
\text { Minerals }\end{array}$ \\
\hline VIVT4 & Telefônica Brasil SA & $\begin{array}{l}\text { Communications / Telecommunications / } \\
\text { Telecommunications }\end{array}$ \\
\hline VVAR3 & Via Varejo SA & $\begin{array}{l}\text { Cyclical Consumption / Commerce / } \\
\text { Household Appliances }\end{array}$ \\
\hline WEGE3 & WEG SA & $\begin{array}{l}\text { Industrial Goods / Machinery and } \\
\text { Equipment / Engines, Compressors and } \\
\text { Others }\end{array}$ \\
\hline YDUQ3 & YDUQS PARTICIPACOES & $\begin{array}{l}\text { Cyclical Consumption / Miscellaneous / } \\
\text { Educational Services }\end{array}$ \\
\hline
\end{tabular}

